\title{
Article \\ Structural and Chemical Adaptations of Artemisia monosperma Delile and Limbarda crithmoides (L.) Dumort. in Response to Arid Coastal Environments along the Mediterranean Coast of Egypt
}

\author{
Ghada A. El-Sherbeny ${ }^{1, *(\mathbb{D})}$, Mohammed A. Dakhil ${ }^{2}\left(\mathbb{D}\right.$, Ebrahem M. Eid $^{3,4}{ }^{(D)}$ and Mohamed Abdelaal ${ }^{1, *(D)}$ \\ 1 Department of Botany, Faculty of Science, Mansoura University, Mansoura 35516, Egypt \\ 2 Botany and Microbiology Department, Faculty of Science, Helwan University, Cairo 11790, Egypt; \\ mohamed_dakhil@science.helwan.edu.eg \\ 3 Biology Department, College of Science, King Khalid University, Abha 61321, Saudi Arabia; \\ ebrahem.eid@sci.kfs.edu.eg or eeid@kku.edu.sa \\ 4 Botany Department, Faculty of Science, Kafrelsheikh University, Kafr El-Sheikh 33516, Egypt \\ * Correspondence: ghada204@mans.edu.eg (G.A.E.-S.); mohamed_eco@mans.edu.eg (M.A.)
}

\section{check for} updates

Citation: El-Sherbeny, G.A.; Dakhil, M.A.; Eid, E.M.; Abdelaal, M. Structural and Chemical Adaptations of Artemisia monosperma Delile and Limbarda crithmoides (L.) Dumort. in Response to Arid Coastal Environments along the Mediterranean Coast of Egypt. Plants 2021, 10, 481. https://doi.org/ 10.3390/plants10030481

Academic Editor: Anelia Dobrikova

Received: 7 February 2021

Accepted: 1 March 2021

Published: 4 March 2021

Publisher's Note: MDPI stays neutral with regard to jurisdictional claims in published maps and institutional affiliations.

Copyright: (c) 2021 by the authors Licensee MDPI, Basel, Switzerland. This article is an open access article distributed under the terms and conditions of the Creative Commons Attribution (CC BY) license (https:// creativecommons.org/licenses/by/ $4.0 /)$.

\begin{abstract}
Arid coastal habitats are stressful regions subjected to the effects of biotic and abiotic factors. Vascular plants in these habitats display different responses to cope with these environmental fluctuations. This work addressed the morpho-anatomical features and chemical responses of two medicinal vascular plant species Artemisia monosperma Delile and Limbarda crithmoides (L.) Dumort., growing naturally along the Mediterranean coast of Egypt. Soil properties (physical and chemical), morpho-anatomical features and chemical constituents (secondary metabolites, antioxidant activity and essential oils) for the two species were performed. Our results displayed that both species are surviving where soils are alkaline, high saline with low moisture and organic carbon. The morphology of both species appeared woody low shrub with fleshy leaves. The most marked anatomical attributes were the thick cuticle of the epidermal layer in leaves and stems, compact palisade cells and abundant idioblasts (secretory ducts, phenolic compounds and calcium oxalate). Also, sclerenchymatous pericycle fibers in stem and glandular trichomes on the leaf had appeared in A. monosperma. Both plants exhibited a considerable content of phenolics, flavonoids, tannins, alkaloids and antioxidant activity with a higher level in A. monosperma than L. crithmoides. The leaf extracts of both plants showed higher values than the stem extracts. The sesquiterpenes group were the major identified compounds of the essential oils (EOs) in A. monosperma and L. crithmoides, and the majority were oxygenated sesquiterpenes with percentages of $42.63 \%$ and $51.49 \%$, respectively. The second major group of EOs was monoterpenes, which were represented in A. monosperma in concentrations (34.04\%) much higher than those recorded in L. crithmoides (4.97\%). Exploring the local adaptation mechanism used by the target plants helps us to understand how these plants can acclimatize to harsh conditions, and this provides critical insights into the protection and survival strategy of species under extreme conditions.
\end{abstract}

Keywords: adaptation; anatomy; drought; essential oils; salinity; phytochemistry

\section{Introduction}

Fluctuation in the structure and function of the ecosystem is generally an output of the interactions between its biotic and abiotic components. These interactions are critical in harsh environmental conditions of coastal and arid lands, so any defect in any component of the ecosystem leads to fundamental changes in others, thus establishing a distinct microhabitat [1]. Coastal habitats are depicted by harsh conditions owing to the impacts of biotic and abiotic factors. These conditions stimulate a zonation of plant communities and high ecological diversity along a gradient from the coastal to inland regions $[2,3]$. 
Egypt's Mediterranean coastal land is a part of the dry arid climatic areas and is threatened by natural and anthropogenic factors $[4,5]$. The most significant abiotic stress agents that affect plant communities in the coastal and arid habitat are climatic-induced processes of erosion and deposition, temperature, drought, salinity, substrate instability and nutrient deficiency $[3,6]$. Biotic stress is induced not only by human impacts but also by other living organisms such as herbivores, weeds (allelopathy and competition) and parasites [5,7]. Consequently, plant species of these habitats acquired different adaptation or avoidance strategies against stressful abiotic and biotic agents. Such strategies include adaptation like modifications of morphological and anatomical structures, plant chemo-strategies, antioxidant activity, etc. [8-10]. Morpho-anatomical characters of different plant organs growing in harsh conditions are deemed significant as acclimatization reflects the ecology of a particular species habitat [11]. Some studies have conveyed a relationship between particular morpho-anatomical features and drought stress resistance in plant stems [11,12]. Other researches revealed that the elevated levels of salinity result in anatomical modification like leaf thickness, reduction in stomatal number and idioblasts' appearance [12,13]. On the other hand, plant chemo-strategies include the production of different secondary metabolites (SMs) from the primary constituents. These SMs are defined as constituents that have no essential function in the maintenance of life processes, but they participate in defensive roles as a response to biotic and abiotic stresses [14].

Generally, there is little information about tolerance and avoidance mechanisms of psammophytic and halophytic species in arid-coastal regions. In the present study, two Asteraceae species: Artemisia monosperma Delile and Limbarda crithmoides (L.) Dumort. were selected. The two plant species are among the dominant and poorly-characterized species along the Mediterranean coastal region of Egypt. Artemisia is a genus of small herbs and shrubs. This genus includes more than 500 species distributed in North America, Europe and Asia [15]. Many species of the Artemisia genus are oil-producing and used for medicinal purposes [16]. Artemisia monosperma is a psammophytic shrubby perennial species distributed in the East Mediterranean region and Arabian Peninsula. In Egypt, it grows in desert plains, and inland or coastal wadis within the Mediterranean coastal sector. The medicinal importance of $A$. monosperma is attributed to its anticancer, antimalarial, antispasmodic, antihypertensive and antioxidant activities [17-19]. Also, the insecticidal, larvacidal and antimicrobial properties of $A$. monosperma are due to the bioactive compounds and essential oils (EOs) [20-22]. On the other hand, Limbarda crithmoides (synonymous = Inula crithmoides L.) is natively distributed along the wetlands and salt marshes of the Mediterranean Sea and Europe. In Egypt, it is among the common halophytic medicinal species in the deltaic Mediterranean coast. It is frequently consumed by grazing animals. L. crithmoides is a perennial halophyte with salt-tolerant features, antioxidant, biological activity, and commonly used in traditional medicine [23-27]. Due to its high iodine and vitamin content, L. crithmoides is eaten with vinegar in Lebanon and Spain $[23,28]$.

Globally, salinity and drought reduce the growth and productivity of plants $[29,30]$. Freshwater scarcity is expected to rise in the future and consequently, the impact of abiotic stresses will increase. Therefore, there is an urgent need to understand the adaptation strategies of plants naturally growing in such stressed habitats. We assumed that both selected species are equipped with a specific adaptation strategy that enables them to survive and persist in these harsh conditions. Thus, this study aimed to assess the morphological, anatomical, and chemical behaviors of A. monosperma and L. crithmoides in their arid coastal environments along the Mediterranean coast of Egypt.

\section{Results}

\subsection{Soil Properties}

The soil data in Table 1 showed that the soil texture of site I of A. monosperma was sandy soil, and site II of L. crithmoides was sandy-loamy soil. The soil moisture content varied from $3.50 \%$ to $4.70 \%$, where the water-holding capacity ranged from $50.30 \%$ to $62.86 \%$ at the two sites, respectively. Soil $\mathrm{pH}$ shifted to a moderately alkaline range and 
varied from 7.81 to 8.21 at sites I and II, respectively. Electric conductivity was $6180 \mu \mathrm{S} / \mathrm{cm}$ at the site I and $7730 \mu \mathrm{S} / \mathrm{cm}$ at site II, indicating a high salinity. Bicarbonates, chlorides, and calcium carbonates, which reflect the soil salinity status were higher in site II than the site I. The soils of sites I and II were characterized by a low organic matter content $(0.90 \%$ and $1.40 \%$, respectively).

Table 1. Soil properties (mean values \pm standard error) supporting the growth of $A$. monosperma (Site I) and L. crithmoides (Site II). Different letters in the same row are significantly different at $p<0.05$.

\begin{tabular}{ccc}
\hline Scheme & Site I & Site II \\
\hline Sand (\%) & $95.20 \pm 1.80^{\mathrm{a}}$ & $50.72 \pm 0.90^{\mathrm{b}}$ \\
Silt (\%) & $3.50 \pm 0.85^{\mathrm{a}}$ & $42.88 \pm 1.50^{\mathrm{b}}$ \\
Clay (\%) & $1.20 \pm 0.10^{\mathrm{a}}$ & $6.40 \pm 0.30^{\mathrm{b}}$ \\
Moisture content $(\mathrm{MC}, \%)$ & $3.5 \pm 0.90^{\mathrm{a}}$ & $4.70 \pm 0.08^{\mathrm{b}}$ \\
Water holding capacity $(\mathrm{WHC}, \%)$ & $41.30 \pm 1.50^{\mathrm{a}}$ & $62.86 \pm 2.30^{\mathrm{b}}$ \\
pH & $7.81 \pm 0.30^{\mathrm{a}}$ & $8.21 \pm 0.50^{\mathrm{a}}$ \\
Electric conductivity $(\mathrm{EC}, \mu \mathrm{S} / \mathrm{cm})$ & $6180 \pm 112.0^{\mathrm{a}}$ & $7730 \pm 67.80^{\mathrm{b}}$ \\
$\mathrm{HCO}_{3}(\%)$ & $0.09 \pm 0.0^{\mathrm{a}}$ & $0.12 \pm 0.0^{\mathrm{a}}$ \\
$\mathrm{Cl}^{-}(\%)$ & $0.64 \pm 0.02^{\mathrm{a}}$ & $1.10 \pm 0.06^{\mathrm{b}}$ \\
$\mathrm{SO}^{-}(\%)$ & $0.65 \pm 0.05^{\mathrm{a}}$ & $0.70 \pm 0.0^{\mathrm{a}}$ \\
$\mathrm{CaCO}_{3}(\%)$ & $11.0 \pm 1.00^{\mathrm{a}}$ & $7.0 \pm 0.50^{\mathrm{b}}$ \\
Organic carbon $(\mathrm{OC}, \%)^{\mathrm{a}} \mathrm{ca}$ & $1.40 \pm 0.04^{\mathrm{b}}$ \\
\hline
\end{tabular}

\subsection{Morphological and Anatomical Features of A. monosperma and L. crithmoides}

Artemisia monosperma is a woody glabrous low shrub with numerous branched stems and pallid green fleshy leaves. Leaves of vegetative branches are oblanceolate in outline, pinnatisect, with linear acute lobes oblong to slightly clasping at the base (Figure 1A). L. crithmoides is a woody glabrous low shrub, glabrous, solid, long and cylindrical stem, with lateral monopodial nature of branching and has active floral terminal and vegetative axillary buds. (Figure 2A).
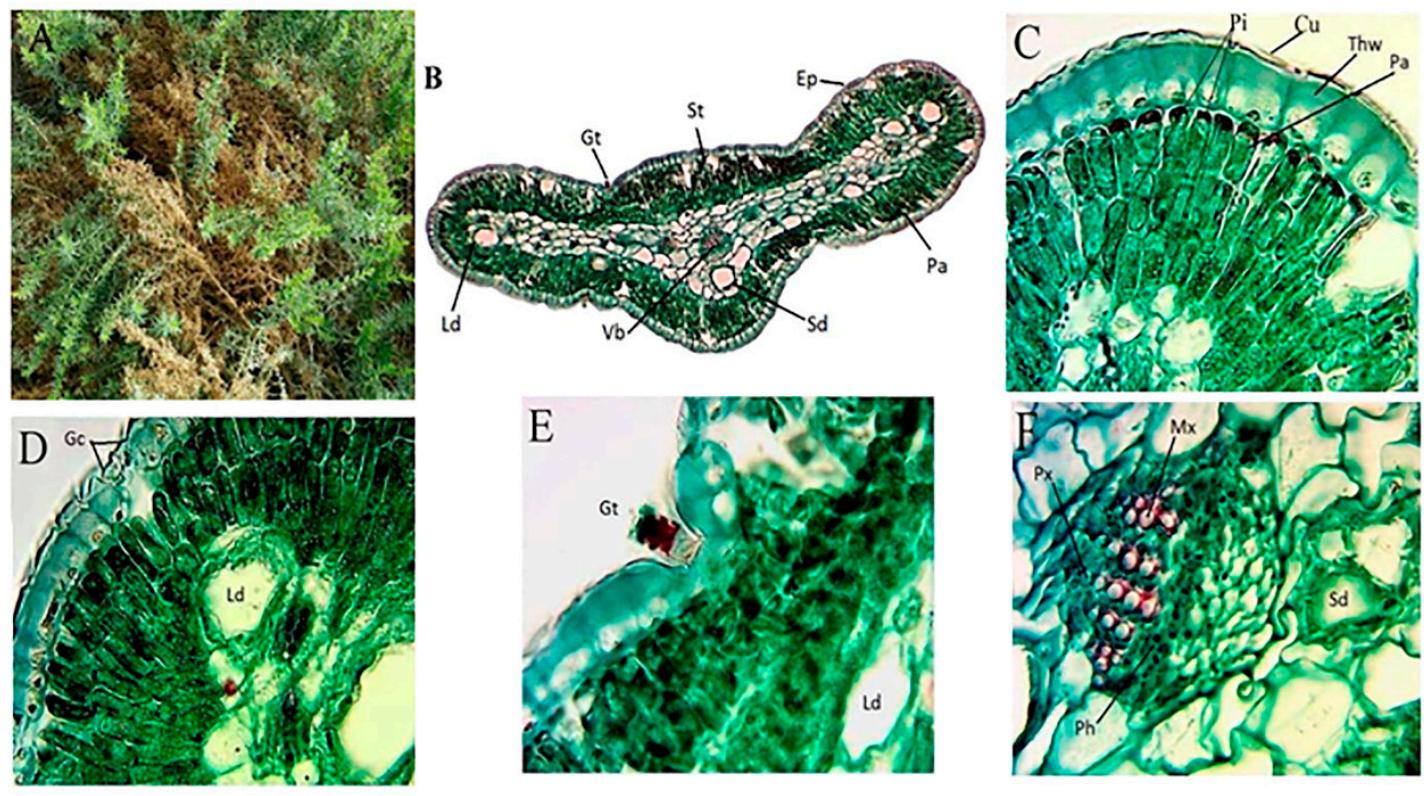

Figure 1. Morphology and anatomy of A. monosperma leaf. (A) Morphology; (B) A transverse section in leaf showing the general view, Ep: epidermis, St: stomata, Pa: palisade tissue, Sd: schizogenous duct, Vb: vascular bundle; (C) cuticle (Cu), Thw: thick wall, Pa: palisade tissue, Pi: phenolic idioblasts; (D) guard cells (Gc), Ld: lysigenous duct; (E) glandular trichomes $(\mathrm{Gt})$ and $(\mathrm{F})$ enlarged vascular bundle $(\mathrm{Vb}), \mathrm{Mx}$ : metaxylem, Px: protoxylem, Ph: phloem. Bar: B = 40 $\mu \mathrm{m}$, $\mathrm{C}-\mathrm{F}=400 \mu \mathrm{m}$. 

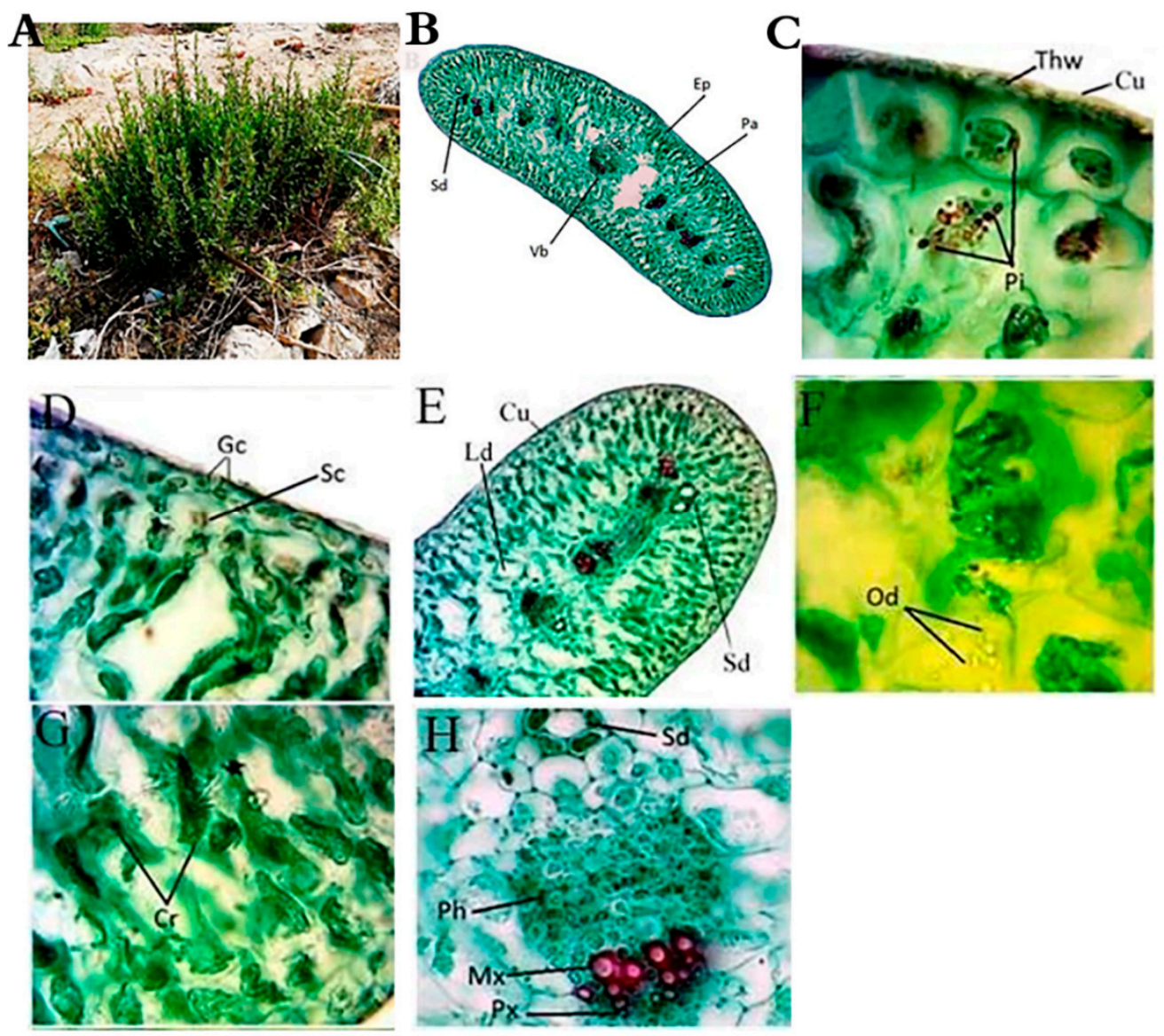

Figure 2. Morphology and anatomy of L. crithmoides leaf. (A) Morphology, (B) A transverse section in leaf showing the general view, Ep: epidermis, Pa: palisade tissue, $\mathrm{Sd}$ : schizogenous duct, $\mathrm{Vb}$ : vascular bundle; (C) phenolic idioblasts (Pi), Thw: thick wall, Cu: cuticle; (D) guard cells (Gc), Sc: substomatal chamber; (E) lysigenous duct (Ld), Sd: schizogenous duct, Cu: cuticle; (F) Oil drops (Od); (G) crystals (Cr) and (H) enlarged vascular bundle (Vb), Mx: metaxylem, Px: protoxylem, Ph: phloem, Sd: schizogenous duct. Bar: $\mathrm{B}=40 \mu \mathrm{m}, \mathrm{C}-\mathrm{H}=400 \mu \mathrm{m}, \mathrm{E}=100 \mu \mathrm{m}$.

The leaf shape of A. monosperma is isobilateral while the shape of L. crithmoides is cylindrical bifacial (Figures 1 and 2B). The outer walls of the epidermis were covered by a thick wall and cuticle layer in the two studied plants (Figures $1 \mathrm{C}$ and 2C). In both plants, the stomata have small guard cells and a well-defined substomatal chamber, but their abundance was higher on the A. monosperma leaf. The mesophyll region consists of elongated and compactly arranged palisade cells in both plants where the central region is occupied by thin-walled living spongy parenchyma in A. monosperma and loosely arranged spongy parenchyma with intercellular spaces in L. crithmoides (Figures 1D and 2D). Phenolic idioblasts were noticed in the epidermal and subepidermal layers which appeared in a black red color in both plants (Figures $1 \mathrm{C}$ and $2 \mathrm{C}$ ). Also, there are many schizogenous and lysigenous ducts within the spongy tissue in both plants (Figure 1B,D,E,F and Figure $2 \mathrm{~B}, \mathrm{E}, \mathrm{H}$, respectively), but the abundance was higher in A. monosperma. The epidermal layer of $A$. monosperma was featured by glandular trichomes which were absent in L. crithmoides leaf (Figure 1E). Calcium oxalate crystals and oil drops were recorded in L. crithmoides leaf (Figure 2G,F). The vascular bundles were open collateral with hardly distinguishable cambium (Figures $1 \mathrm{~F}$ and $2 \mathrm{H}$, respectively).

The cross-sections in the stems of $A$. monosperma and L. crithmoides showed typical dicot stems with an epidermis of a single layer of compact barrel-shaped cells without intercellular spaces covered with a thick cuticle (Figures 3A and 4A). The stem shape of A. monosperma is wavy, so the cortex consists of the protuberance, which is composed of 
5-8 layers of collenchyma, and furrows, which consists of 3-4 layers of chlorenchyma. On the other hand, the stem of L. crithmoides is circular in transverse section with the cortical parenchyma zone composed of 4-9 layers of irregular isodiametric parenchymatic cells. Also, the cortex layer is characterised by the presence of schizogenous and lysigenous cavities in A. monosperma (Figure 3A,D) whereas L crithmoides is characterised by abundant schizogenous ducts (Figure 4A,B,E). Calcium oxalate of druses and prismatic types were recorded in $A$. monosperma (Figure 3B,C), and abundant raphids were recorded in L. crithmoides (Figure 4D,E). Phenolic compounds and oil drops near the outer cortical cell of the stem were observed in A. monosperma (Figure 3D) and L. crithmoides (Figure 4D,F,G). Well-developed conductive tissues consist of xylem and phloem in open collateral vascular bundles in both plants. Beneath the endodermis, there is a massive zone of sclerenchymatous polygonal pericycle fibers which form a cap-like structure over the bundles in A. monosperma (Figure 3E).

\subsection{Phytochemical Analysis of A. monosperma and L. crithmoides}

\subsubsection{Secondary Metabolites}

The results displayed in Figure 5 revealed that both studied plants possess a considerable content of total phenols, flavonoids, tannins and alkaloids with higher content in A. monosperma than in L. crithmoides. The leaf extracts of both plants exhibited higher values than stem extracts.

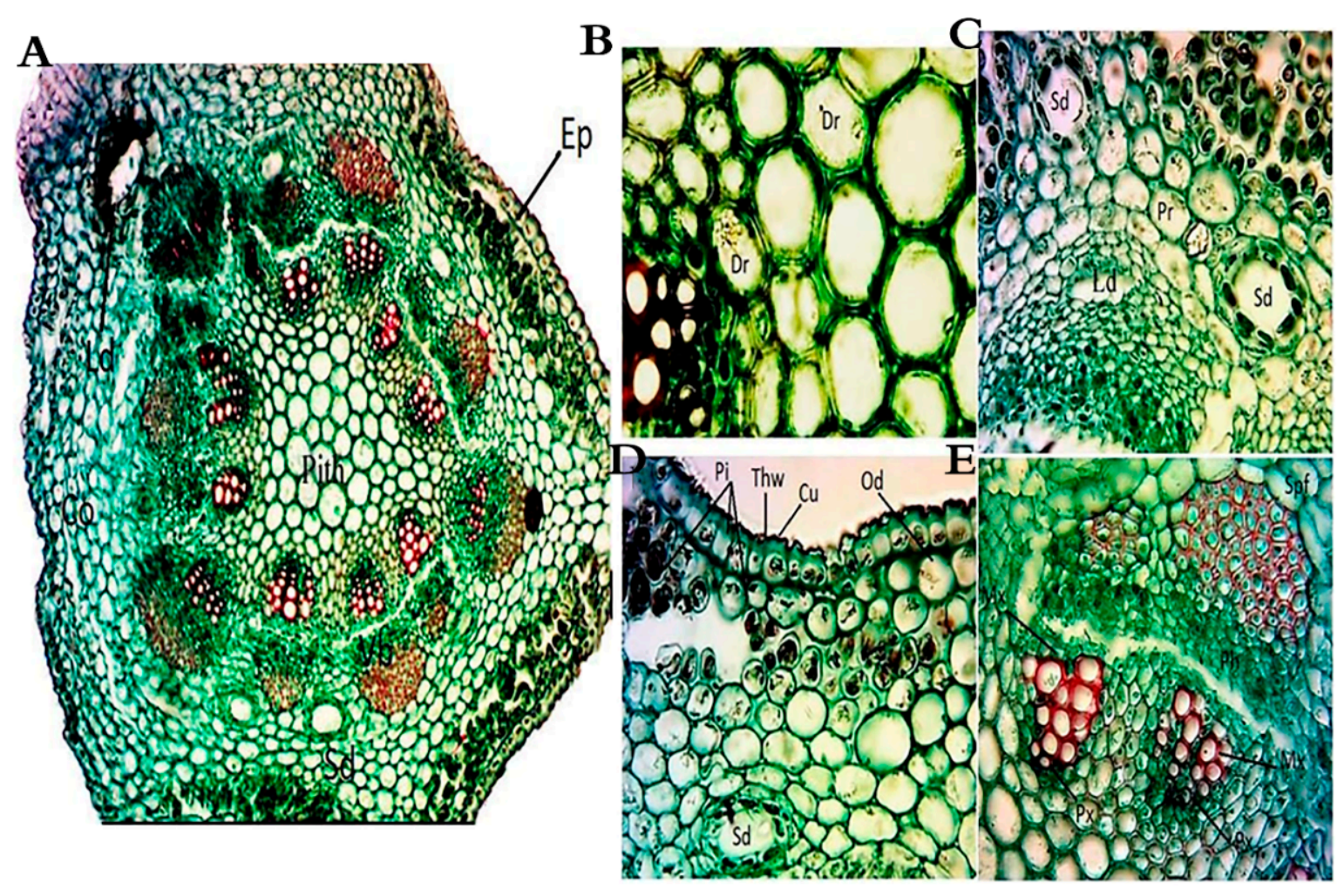

Figure 3. Anatomy of A. monosperma stem. (A) A transverse section in stem, Ep: epidermis, Co: cortex, Lc: lysigenous duct, Sd: schizogenous duct, Vb: vascular bundle; (B) Druses crystals (Dr); (C) Prismatic crystals (Pr), Lc: lysigenous duct, Sd: schizogenous duct; (D) thick wall (Thw), Cu: cuticle, Pi: phenolic idioblasts, Od: oil drops; (E) enlarged vascular bundle (Vb), Mx: metaxylem, Px: protoxylem, Ph: phloem, Spf: sclerenchymatous pericycle fibers. Bar: $A=40 \mu \mathrm{m}, \mathrm{B}-\mathrm{F}=400 \mu \mathrm{m}$. 

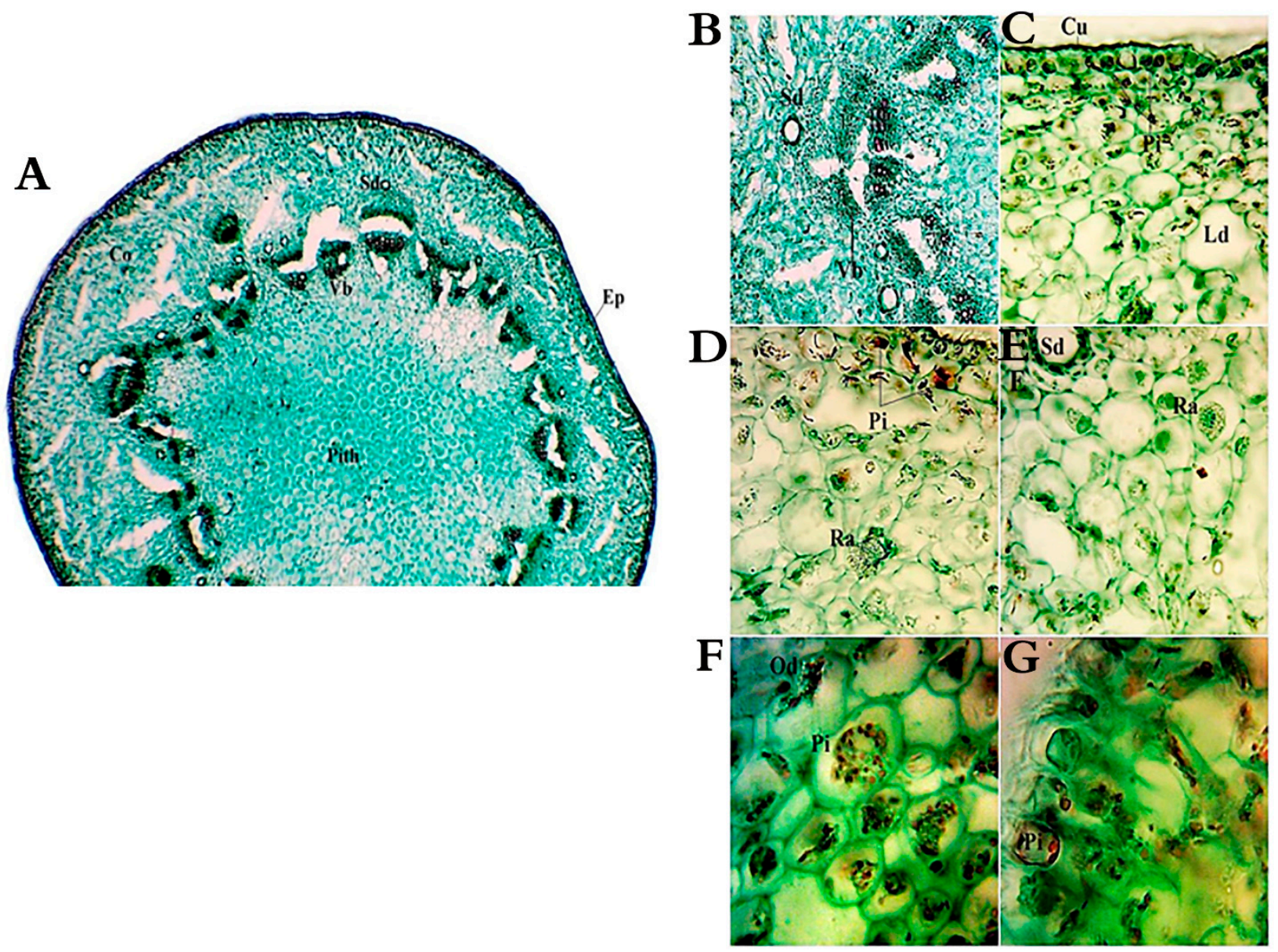

Figure 4. Anatomy of L. crithmoides stem. (A) A transverse section in stem, Ep: epidermis, Co: cortex, Sd: schizogenous duct, Vb: vascular bundle; (B) enlarged vascular-bundle $(\mathrm{Vb}) ;(\mathbf{C})$ cuticle $(\mathrm{Cu})$, Pi: phenolic idioblasts, Ld: lysigenous duct; $(\mathrm{D}, \mathrm{E})$ raphides crystals $(\mathrm{Ra}) ;(\mathrm{F}, \mathrm{G})$ oil drops $(\mathrm{Od})$. Bar: A $=40 \mu \mathrm{m}, \mathrm{B}-\mathrm{E}=100 \mu \mathrm{m}, \mathrm{F}-\mathrm{G}=400 \mu \mathrm{m}$.

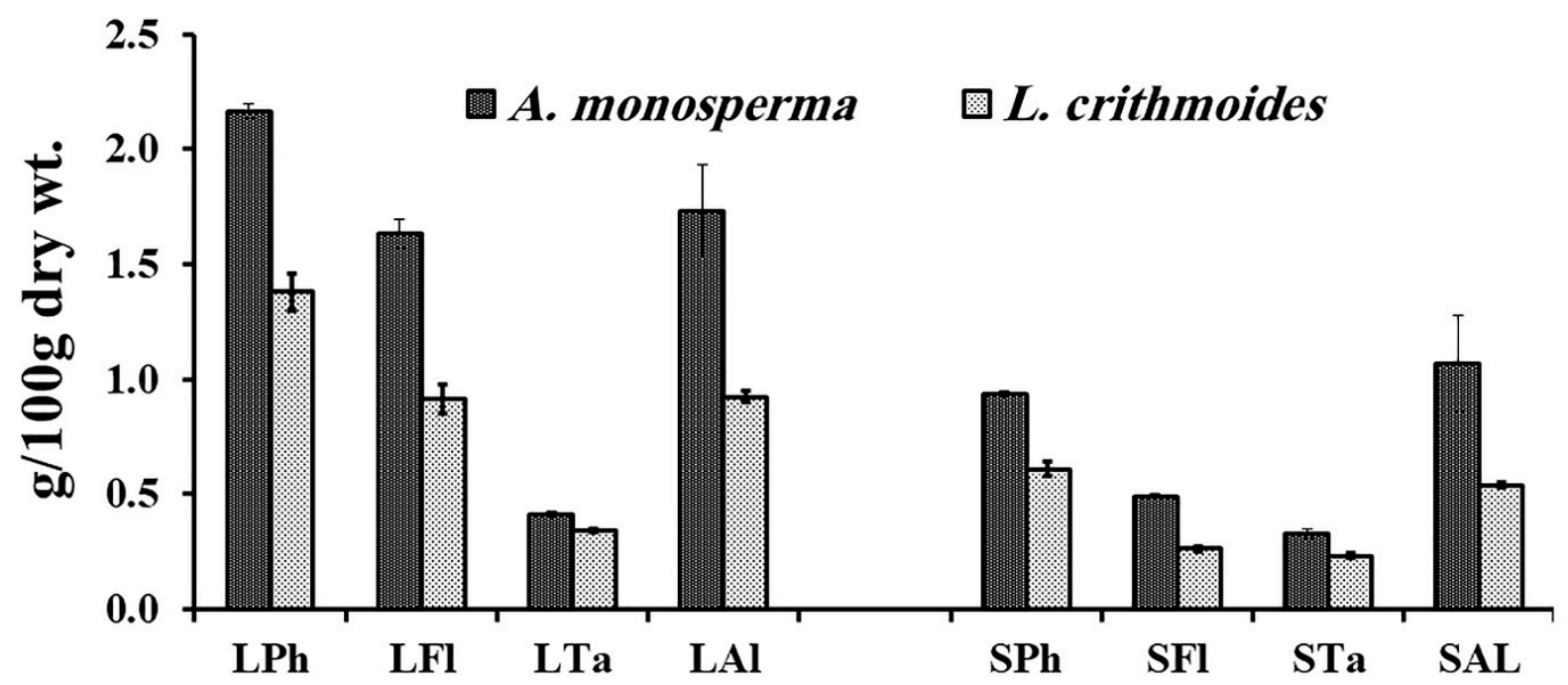

Figure 5. Phytochemical analysis of leaves and stems of A. monosperma and L. crithmoides. $\mathrm{L}=$ leaf, $\mathrm{S}=\mathrm{stem}, \mathrm{Ph}=\mathrm{phenols}$ ( $\mathrm{g}$ GAE /100 g dry wt), Fl = flavonoids (g CE/100 g dry wt.), Ta = tannins ( $\mathrm{g}$ TAE/100 g dry wt), Al = alkaloids (g/100 g dry wt.). GAE: gallic acid equivalents, CE: catechin equivalents, TAE: tannic acid equivalents. 
The total phenols content in $A$. monosperma leaves $(2.17 \mathrm{~g}$ gallic acid equivalents (GAE)/100 g dry wt.) was higher than that in L. crithmoides leaves (1.38 g GAE/100 g dry wt.) with a significant difference $(\mathrm{t}=15.8, p<0.001)$. Total phenols content in stems significantly differed between $L$. crithmoides (0.93 g GAE/100 g dry wt.) and A. monosperma (0.61 g GAE / $100 \mathrm{~g}$ dry wt.). The flavonoids content in $A$. monosperma leaves (1.63 catechin equivalents (CE)/100 g dry wt.) was significantly $(\mathrm{t}=17.8, p<0.0001)$ higher than that of L. crithmoides leaves (0.92 CE/100 g dry wt.). Also, the stem showed the same trend where flavonoid content in A. monosperma stem was $0.49 \mathrm{CE} / 100 \mathrm{~g}$ dry wt. and recorded $0.26 \mathrm{CE} / 100 \mathrm{~g}$ dry wt. with a significant difference $(\mathrm{t}=34.0, p<0.0001)$. Tannins concentration in L. crithmoides leaves (0.41 $\mathrm{g}$ tannic acid equivalents (TAE) $/ 100 \mathrm{~g}$ dry wt.) was significantly $(\mathrm{t}=7.4, p<0.01)$ lower than that of $A$. monosperma leaves $(0.34 \mathrm{~g}$ TAE $/ 100 \mathrm{~g}$ dry wt. $)$. Also, the tannins level in the stem ranged from $0.24 \mathrm{~g}$ TAE/100 g dry weight in L. crithmoides to $0.32 \mathrm{~g}$ TAE $/ 100 \mathrm{~g}$ dry weight in A. monosperma $(\mathrm{t}=7.5, p<0.01)$. The alkaloids content in leaves significantly ranged from the highest value in $A$. monosperma $1.73 \mathrm{~g} / 100 \mathrm{~g}$ dry weight to the lowest value in L. crithmoides $0.92 \mathrm{~g} / 100 \mathrm{~g}$ dry weight $(\mathrm{t}=4.6, p<0.05)$. The stem of both plants exhibited a similar trend with a significant difference $(\mathrm{t}=4.4, p<0.01)$ from the highest alkaloids content in A. monosperma stem (0.94 g dry wt.) to the lowest content in L. crithmoides stem (0.54 g dry wt.).

\subsubsection{Antioxidant Activity}

The antioxidant activity of $A$. monosperma and L. crithmoides was estimated by DPPH (1,1-diphenyl-2-picrylhydrazyl) assay which exhibited elevated antioxidant scavenging activities with values higher or equal to that of ascorbic acid in ethanol extract (Figure 6). The ethanolic extracts of $A$. monosperma and L. crithmoides leaves showed significantly different IC50 values, ranging from 0.01 to $0.13 \mathrm{mg} / \mathrm{ml}$, respectively $(\mathrm{t}=-29.7, p<0.0001)$. The antioxidant scavenging activity in stems varied from $0.06 \mathrm{mg} / \mathrm{ml}$ in $A$. monosperma to $0.19 \mathrm{mg} / \mathrm{ml}$ in L. crithmoides $(\mathrm{t}=-27.6, p<0.0001)$.

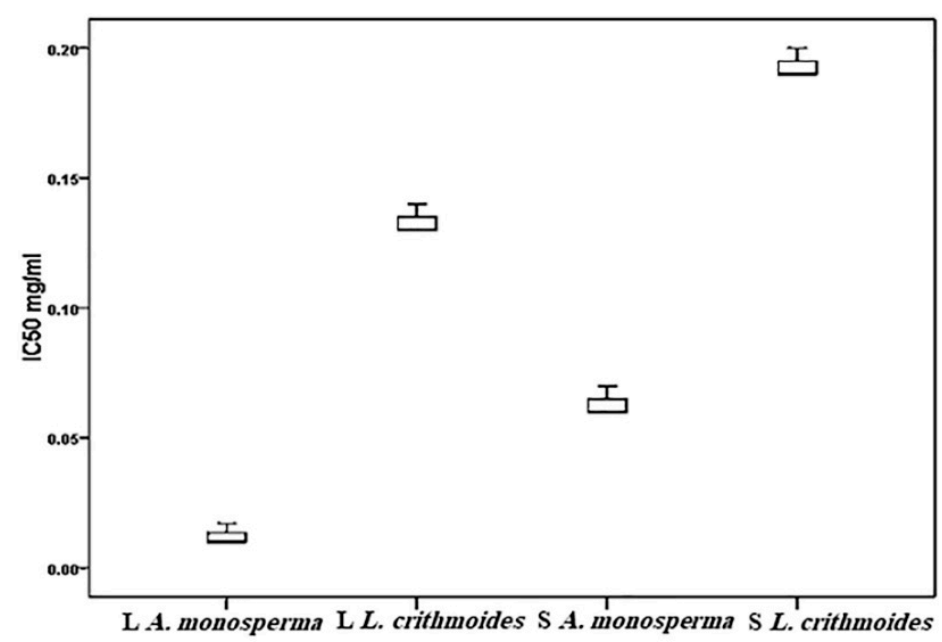

Figure 6. DPPH (1,1-diphenyl-2-picrylhydrazyl) radical scavenging capacity (IC50) in the leaf (L) and stem (S) of A. monosperma and L. crithmoides. Mean values are significantly different at $p<0.05$.

\subsubsection{Essential Oils Characterization}

The chromatograms and structure of the main essential oils (EOs) of A. monosperma and L. crithmoides are shown in the Supplementary Materials (Figures S1 and S2). The results displayed that EOs of $A$. monosperma and L. crithmoides include 30 compounds for each plant (Table 2). Three groups of organic EOs components (monoterpenes, sesquiterpenes and hydrocarbons), in addition to the diterpene group, were recorded in L. crithmoides. 
Table 2. Chemical composition of the essential oil (\%) from A. monosperma and L. crithmoides.

\begin{tabular}{|c|c|c|c|c|c|c|}
\hline No & $\begin{array}{l}\text { A. monosperma } \\
\text { Compounds }\end{array}$ & RT & MW & MF & Concentration $\%$ & $\begin{array}{l}\text { L. crithmoides } \\
\text { Compounds }\end{array}$ \\
\hline \multicolumn{7}{|c|}{ Monoterpene hydrocarbons } \\
\hline 1 & $\alpha$-pinene & 4.25 & 136.24 & $\mathrm{C}_{10} \mathrm{H}_{16}$ & 1.56 & - \\
\hline 2 & $( \pm)$ - $\beta$-pinene & 5.45 & 136.24 & $\mathrm{C}_{10} \mathrm{H}_{16}$ & 6.35 & - \\
\hline 3 & D-limonene & 6.87 & 136.24 & $\mathrm{C}_{10} \mathrm{H}_{16}$ & 2.09 & - \\
\hline 4 & $\gamma$-terpinene & 7.81 & 136.24 & $\mathrm{C}_{10} \mathrm{H}_{16}$ & 1.13 & - \\
\hline 5 & $p$-cymene & 6.79 & \multirow{2}{*}{134.22} & \multirow{2}{*}{$\mathrm{C}_{10} \mathrm{H}_{14}$} & 1.46 & - \\
\hline 6 & - & 14.59 & & & 1.29 & p-cymene \\
\hline \multicolumn{7}{|c|}{ Oxygenated monoterpenes } \\
\hline 7 & linalool & 9.44 & 154.25 & $\mathrm{C}_{10} \mathrm{H}_{18} \mathrm{O}$ & 2.43 & - \\
\hline 8 & $\begin{array}{l}\text { (-)-trans- } \\
\text { pinocarveol }\end{array}$ & 11.10 & 152.24 & $\mathrm{C}_{10} \mathrm{H}_{16} \mathrm{O}$ & 3.37 & - \\
\hline 9 & pinocarvone & 12.01 & 150.22 & $\mathrm{C}_{10} \mathrm{H}_{14} \mathrm{O}$ & 2.59 & - \\
\hline 10 & 4-terpineol & 12.69 & 154.25 & $\mathrm{C}_{10} \mathrm{H}_{18} \mathrm{O}$ & 2.35 & - \\
\hline 11 & $(-)$-myrtenol & 13.45 & 152.23 & $\mathrm{C}_{10} \mathrm{H}_{16} \mathrm{O}$ & 3.72 & \\
\hline 12 & (-)-citronellol & 14.66 & & & 3.01 & - \\
\hline 13 & - & 14.55 & 156.27 & $\mathrm{C}_{10} \mathrm{H}_{20} \mathrm{O}$ & 1.01 & $(-)$-citronellol \\
\hline 14 & - & 15.44 & 148 & $\mathrm{C}_{10} \mathrm{H}_{12} \mathrm{O}$ & 1.00 & $\begin{array}{l}\text { benzaldehyde, } \\
\text { 4-(1-methylethyl)- }\end{array}$ \\
\hline 15 & $\begin{array}{l}\text { cuminic } \\
\text { aldehyde }\end{array}$ & 15.50 & 148.2 & $\mathrm{C}_{10} \mathrm{H}_{12} \mathrm{O}$ & 2.19 & - \\
\hline 16 & bornyl acetate & 16.84 & 196.29 & $\mathrm{C}_{12} \mathrm{H}_{20} \mathrm{O}_{2}$ & 1.79 & - \\
\hline 17 & - & 20.88 & 196.29 & $\mathrm{C}_{12} \mathrm{H}_{20} \mathrm{O}_{2}$ & 1.67 & geranyl acetate \\
\hline \multicolumn{7}{|c|}{ Oxygenated diterpene } \\
\hline 18 & - & 48.83 & 308.51 & $\mathrm{C}_{20} \mathrm{H}_{34} \mathrm{O}_{2}$ & 1.24 & cis-abienol \\
\hline \multicolumn{7}{|c|}{ Non-oxygenated sesquiterpenes } \\
\hline 19 & - & 20.61 & 204.36 & $\mathrm{C}_{15} \mathrm{H}_{24}$ & 1.51 & $\alpha$-gurjunene \\
\hline 20 & $\alpha$-curcumene & 22.19 & & & 5.72 & - \\
\hline 21 & - & 24.99 & 202.34 & $\mathrm{C}_{15} \mathrm{H}_{22}$ & 7.49 & $\alpha$-curcumene \\
\hline 22 & - & 25.13 & 204.36 & $\mathrm{C}_{15} \mathrm{H}_{24}$ & 1.22 & $\alpha$-selinene \\
\hline 23 & & 22.17 & 204.36 & $\mathrm{C}_{15} \mathrm{H}_{24}$ & 1.30 & beta-caryophyllene \\
\hline 24 & - & 24.76 & 204.36 & $\mathrm{C}_{15} \mathrm{H}_{24}$ & 1.46 & germacrene D \\
\hline \multicolumn{7}{|c|}{ Oxygenated sesquiterpenes } \\
\hline 25 & $\begin{array}{c}- \\
(-)-\end{array}$ & 27.93 & 220.36 & $\mathrm{C}_{15} \mathrm{H}_{24} \mathrm{O}$ & 1.02 & ledene oxide-(ii) \\
\hline 26 & $\begin{array}{l}\text { caryophyllene } \\
\text { oxide }\end{array}$ & 28.02 & 220.36 & $\mathrm{C}_{15} \mathrm{H}_{24} \mathrm{O}$ & 1.35 & - \\
\hline 27 & - & 28.89 & & & 2.49 & $(-)$-caryophyllene oxide \\
\hline 28 & $\begin{array}{l}\text { isoaromadendrene } \\
\text { epoxide }\end{array}$ & 28.25 & 220.36 & $\mathrm{C}_{15} \mathrm{H}_{24} \mathrm{O}$ & 1.29 & - \\
\hline 29 & $\begin{array}{c}\text { citronellyl } \\
\text { iso-valerate }\end{array}$ & 28.79 & \multirow{2}{*}{240.39} & \multirow{2}{*}{$\mathrm{C}_{15} \mathrm{H}_{28} \mathrm{O}_{2}$} & 2.76 & - \\
\hline 30 & - & 28.67 & & & 4.09 & citronellyl iso-valerate \\
\hline 31 & $\begin{array}{c}(-)- \\
\text { spathulenol }\end{array}$ & 28.99 & \multirow[t]{2}{*}{220.36} & \multirow[t]{2}{*}{$\mathrm{C}_{15} \mathrm{H}_{24} \mathrm{O}$} & 2.21 & - \\
\hline 32 & - & 28.79 & & & 2.83 & (-)-spathulenol \\
\hline 33 & viridiflorol & 29.57 & \multirow{2}{*}{222.37} & \multirow{2}{*}{$\mathrm{C}_{15} \mathrm{H}_{26} \mathrm{O}$} & 5.62 & - \\
\hline 34 & - & 29.45 & & & 8.15 & viridiflorol \\
\hline 35 & ledol & 29.86 & 222.37 & $\mathrm{C}_{15} \mathrm{H}_{26} \mathrm{O}$ & 1.18 & - \\
\hline 36 & - & 30.07 & 222.37 & $\mathrm{C}_{15} \mathrm{H}_{26} \mathrm{O}$ & 5.66 & cubenol \\
\hline 37 & widdrol & 30.26 & 222.37 & $\mathrm{C}_{15} \mathrm{H}_{26} \mathrm{O}$ & 7.57 & - \\
\hline 38 & $\begin{array}{l}\text { neoclovenoxid- } \\
\text { alcohol }\end{array}$ & 30.44 & 220.36 & $\mathrm{C}_{15} \mathrm{H}_{24} \mathrm{O}$ & 1.20 & - \\
\hline
\end{tabular}


Table 2. Cont.

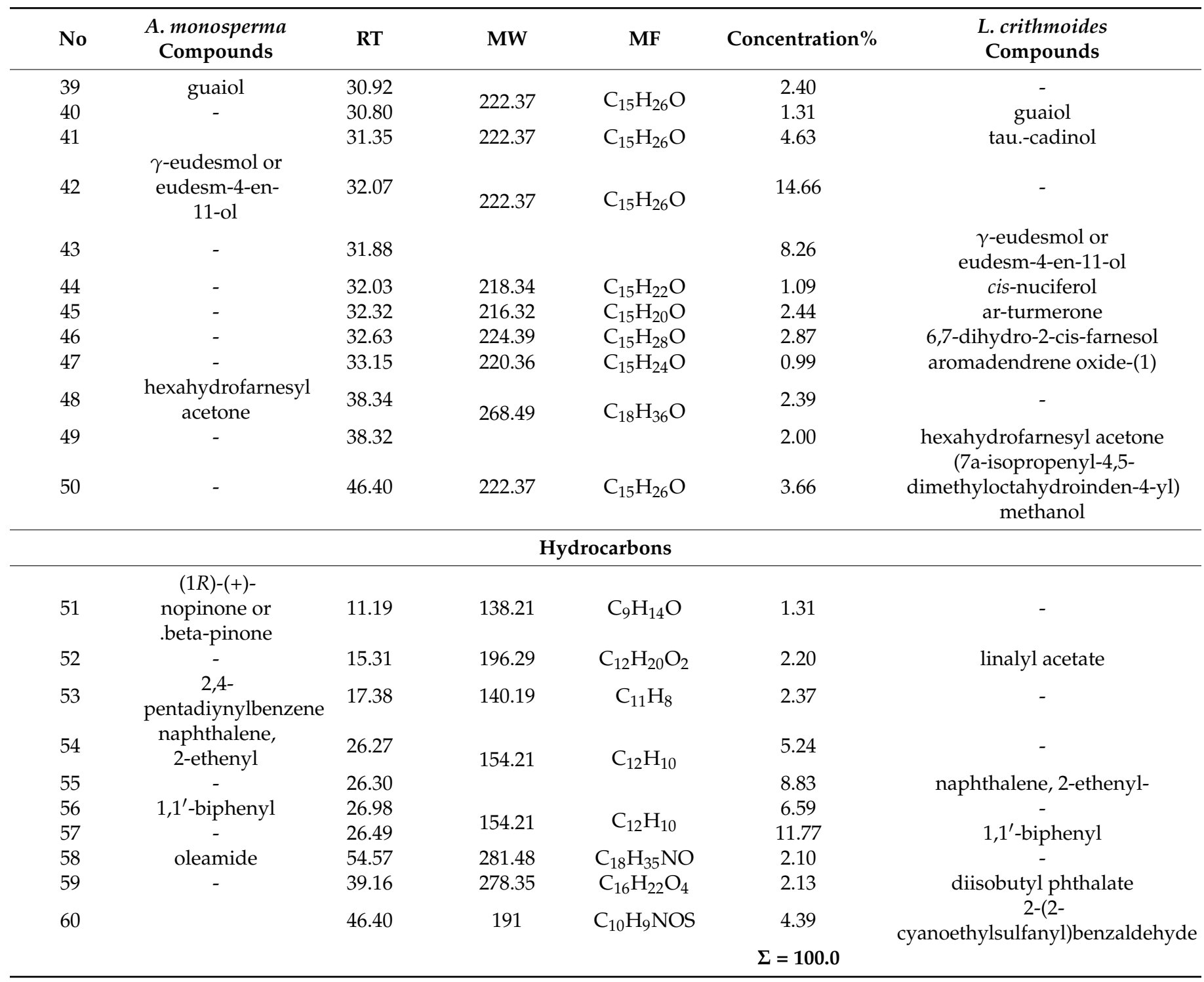

RT: retention time, MW: molecular weight, MF: molecular formula.

The sesquiterpenes group was the major identified compound of the EOs in A. monosperma and L. crithmoides, which recorded $48.35 \%$ and $64.47 \%$, respectively. Grossly, the identified sesquiterpenes were categorized into (1) oxygenated sesquiterpenes with a percentage of $42.63 \%$ and $51.49 \%$, respectively and (2) non-oxygenated sesquiterpenes of $5.72 \%$ and $12.98 \%$, respectively. The common oxygenated sesquiterpenes components in the studied plants were $\gamma$-eudesmol (14.66\% and $8.26 \%$, respectively), viridiflorol $(5.62 \%$ and $8.15 \%$, respectively), citronellyl iso-valerate $(2.76 \%$ and $4.09 \%$ respectively) as well as a considerable content of hexahydrofarnesyl acetone, (-)-spathulenol, guaiol and ( - )-caryophyllene oxide. Concerning non-oxygenated sesquiterpenes compounds, $\alpha$-curcumene $(5.72 \%$ and $7.49 \%$, respectively) was the common between A. monosperma and L. crithmoides and the only non-oxygenated sesquiterpenes compound recorded in A. monosperma. While, $\alpha$-gurjunene, $\alpha$-selinene, beta-caryophyllene, germacrene $\mathrm{D}$ were recorded in L. crithmoides.

The second major detected group of EOs was monoterpenes, which are represented in A. monosperma with a concentration (34.04\%) greatly higher than that recorded in L. crithmoides $(4.97 \%)$. Overall, this group includes oxygenated monoterpenes with a percentage of $21.45 \%$ and $3.68 \%$, respectively, where $(-)$-citronellol $(3.01 \%$ and 1.01 , respectively) was the common compound between the studied plants. Other oxygenated monoter- 
penes in A. monosperma were linalool, (-)-trans-pinocarveol, pinocarvone, 4-terpineol, (-)-myrtenol, cuminic aldehyde, and bornyl acetate as well as in L. crithmoides, benzaldehyde, 4-(1-methylethyl)- and geranyl acetate were detected. Concerning the second group of monoterpenes, monoterpene hydrocarbons of EOs were $12.59 \%$ and $1.29 \%$ in A. monosperma and L. crithmoides, respectively. Only $p$-cymene $(1.46 \%$ and $1.29 \%$, respectively) was the common between the two plants and the only monoterpene hydrocarbon recorded in L. crithmoides. Other monoterpene hydrocarbons in A. monosperma were $( \pm)-\beta$ pinene $(6.35 \%)$, D-limonene $(2.09 \%), \alpha$-pinene, and $\gamma$-terpinene.

The oxygenated diterpene EOs were only detected in L. crithmoides and represented only by one compound cis-abienol (1.24\%). Finally, the hydrocarbons EOs group varied from $17.61 \%$ in $A$. monosperma to $29.32 \%$ in L. crithmoides. The common hydrocarbons between the two plants were $1,1^{\prime}$-biphenyl $(6.59 \%$ and $11.77 \%$ respectively) and naphthalene, 2-ethenyl (5.24\% and $8.83 \%$, respectively).

\section{Discussion}

In this study, the coastal soil supporting the studied plants (A. monosperma and L. crithmoides) was characterized by its alkaline range, sandy to sandy-loamy texture, low moisture content, low water holding capacity, low fertility and high salinity. These results agreed with studies that reported that the Mediterranean regions have different types of soils and featured by a low organic matter content, slightly acidic to alkaline $\mathrm{pH}$ and medium to low fertility [3,5]. The deficiency of organic matter (fertility) may be attributed to the low content of micro-organisms in arid soils which lead to a reduction in the soil water-holding capacity [31].

The plants growing in saline habitats have manifested various strategies that help them to cope with these extreme habitats. Such strategies are often exhibited in the morphological, anatomical, and phytochemical alterations of plants [12,32]. Morphologically, A. monosperma and L. crithmoides plants are featured by their shrubby hard, and woody stems, which aid to resist wind in coastal habitats. The fleshy features of leaves in both studied plants may be due to excessive mucilage to store maximum water, which has a significant role in the dilution of salt concentrations [29].

Also, the leaves of both studied plants were reduced in size which helps them to avoid excessive transpiration. Microscopy investigation revealed that the leaf surface is covered by a thick cuticle and waxy layer to reduce water loss from the leaf surface which is completely justified by the improved tolerance to extreme moisture $[11,33]$. The leaf shape of A. monosperma is isobilateral, which is reported as a prevalent feature of plants growing in arid and hot habitats to decrease leaves' heating and transpiration requirements [34]. L. crithmoides leaf is rather cylindrical which protects the stomata that occur in furrows and prevent direct contact to the atmosphere. In L. crithmoides, the stomata were very reduced in number and size per area. The mesophyll region consists of compactly arranged chloroplast containing cells; this compact arrangement helps to check transpiration. Also, the palisade cells remain radially elongated to minimize the direct penetration of light [34].

The stem of $A$. monosperma is featured by its wavy shape and its cortex which is differentiated into collenchyma and chlorenchyma. The main function of collenchyma cells is to strengthen the organ, while the chlorenchyma aids in the photosynthesis process. The epidermal wall of both plant stems is featured by a thick wall, which can reduce water loss and contribute to the plant bearing high temperatures [35]. The stem of $A$. monosperma was characterized by the presence of cap-like sclerenchymatous fibers at the vascular bundle side, which provide hardness to the stem and hence are difficult to chew with the wind. These results agreed with $[13,35,36]$.

There are abundant lysigenous and schizogenous ducts spread within the spongy tissue in the leaves and cortex of the stem in the studied plants. Also, idioblasts containing calcium oxalate crystals are found in the spongy leaf tissue of L. crithmoides. In this context, the presence of secretory structures in certain families, such as Asteraceae and Fabaceae, gave more adaptive prosperity in multiple environments [36]. Moreover, the appearance 
of secretory organs in the same family was reported for Asteraceae, Fabaceae, Salicaceae, Moraceae, Araceae and Cornaceae that are widely distributed in tropical areas [36]. Secreted compounds may be greatly affected (increased or decreased) when the plant is exposed to various environmental stresses, like infections, wounds or edaphic or climatic factors [37].

The plants' secondary metabolites (SMs) are considered as chemo-strategies for defense reactions to environmental stresses as drought and salinity $[38,39]$. As a protection against these conditions, oxidative stress was induced as antioxidants. The antioxidants can be classified into two classes, enzyme antioxidants, and non-enzymatic constituents part of the non-enzymatic constituents, the secondary plant metabolites comprising the flavonoids and non-flavonoid polyphenols [40,41].

The results obtained revealed that $A$. monosperma and L. crithmoides possess a considerable amount of SMs as phenolics, flavonoids, tannins and alkaloids in extracts of their leaves and stems. Some studies reported that the rise of salinity results in an increase in the content of plant polyphenol as in the alkaloids content of Achillea fragrantissima and Solanum nigrum [42]. On the other hand, in response to drought, there is a rise in the level of plant secondary metabolites as in Catharanthus roseus, Hypericum brasiliense and Artemisia annua [42]. Moreover, a noticeable variation in the levels of volatile compounds was recorded in Thymus vulgaris under water-stress conditions [43].

Volatile compounds are a group of secondary metabolites that mainly comprises mono and sesquiterpene hydrocarbons and their oxygenated derivatives, aldehydes, esters and alcohols [44]. Plant volatile oils are intended to mediate a plant's relationship to abiotic agents as salinity, light, drought, temperature, and biotic agents like microbial pests, herbivores, etc. [45,46].

The results showed that the extracts of A. monosperma and L. crithmoides include different classes of monoterpenes, sesquiterpenes, and hydrocarbons which exhibited the majority of estimated components. The major classes of essential oils (EOs) in A. monosperma extract were oxygenated sesquiterpene and oxygenated monoterpenes, while in L. crithmoides the major classes of EOs were oxygenated sesquiterpene and hydrocarbons. In this context, it was reported that sesquiterpenes are an essential category of organic constituents produced by plants and are distinctive of Asteraceae. The majority of these constituents are volatiles which play a role in communication and defense against herbivory $[47,48]$. For example, in Inula montana exposed to different abiotic stresses such as drought, large amounts of sesquiterpenes were recorded [49]. Also, the higher concentration of oxygenated monoterpens and comparable concentration of oxygenated sesquiterpene in A. monosperma than L. crithmoides results in the elevated content of the antioxidant activity of $A$. monosperma compared with $L$. crithmoides [50,51].

$\gamma$-eudesmol as bicyclic sesquiterpenoid alkene alcohol was found in all tissues, and it was generally decreasing. It can display moderate activity against human diseases. $\alpha$-farnesene as another compound can be effective against the bacteria that cause tooth decay [52]. This variety of EOs recorded in A. monosperma and L. crithmoides matched with other studies which proved the improvement in the SMs was observed in some EO species in response to salinity as in Mentha pulegium [53] and rise EOs in Salvia officinalis [54]. Thus, the enhancement of oil production in response to salinity can be considered as an adaptation to this stress. In this context, the free volatiles are glycosylated that stored in cell vacuoles and intern rise cellular swelling to reduce the effect of osmotic stress from salinity. Charles and Simon [55] attributed the EOs productivity to higher oil gland density.

Water stress also, causes an improvement in EOs production as in Salvia officinalis, Petroselinum crispum and Lippia berlandieri [56]. This revealed that plants subjected to drought stress progress higher quantities of SMs in their tissues [55]. This could be due to a reduction in the area of the leaves, which leads to increase oil glands and intern an increased amount of oil content under drought stress [57]. In addition, Ben Taarit et al. [58] revealed that stress might raise the number of glands produced previous to leaf appearance by early divisions in leaves epidermal cells. Drought stress causes both cellular and intercellular 
oxidative stress. Because SMs have strong antioxidant features, they may be associated with a mechanism to combat the harmful effects of reactive-oxygen species (ROS) [41].

\section{Materials and Methods}

\subsection{Study Site}

The current study was done during August- September 2019 in two sites: site I at New Damietta (latitude 31.42 and longitude 31.82) where A. monosperma is growing on sand formation habitats and site II at Abu Qir, Alexandria (latitude 31.31 and longitude 30.06) where L. crithmoides is growing on wetlands habitats. Both sites are extended within the central part of the Mediterranean coast of Egypt. The bioclimatic map indicates that the middle region of the Mediterranean coast of Egypt belongs to the sub-desertic warm climate [59]. The mean annual temperature is $20^{\circ} \mathrm{C}$, with annual rainfall varied from 91.6 to $175.2 \mathrm{~mm}$. Mean relative humidity is higher in winter $(81 \%)$ than in summer (65\%).

\subsection{Soil Sampling and Analysis}

A composite soil sample $(n=5)$ at a profile of $30 \mathrm{~cm}$ was collected from the growth area of the studied plants. Soil analysis was carried out according to Estefan et al. [60]. The soil moisture was estimated by subtraction of the oven-dry weight of soil from a known fresh-weight and expressed as a percentage of oven-dry weight. Soil texture was detected by the sieves method. Water holding capacity was measured by using the Hilgard's pan box. The $\mathrm{pH}$ and electric conductivity (EC) of the prepared soil extract $(1: 5 w / v)$ were measured using a multi-parameter meter CONSORT Model 535, handheld. Bicarbonates were estimated through titration against $0.1 \mathrm{~N} \mathrm{HCl}$ with phenolphthalein (ph.ph) indicator. Chlorides content was measured by titration against $\mathrm{AgNO}_{3}$ in the presence of potassium dichromate. Sulfates content was spectrophotometrically valued after adding $0.15 \%$ calcium chloride dehydrate. Calcium carbonates were measured after precipitation using $0.5 \mathrm{M} \mathrm{HCl}$, then titration against $0.5 \mathrm{M} \mathrm{NaOH}$ in the presence of ph indicator. The organic carbon content was detected by titration with standard $\mathrm{FeSO}_{4}$ after digestion with chromic and sulphuric acids.

\subsection{Plant Samples Collection and Analysis}

\subsubsection{Samples Collection}

Healthy samples $(n=5)$ from stem and leaves of A. monosperma. and L. crithmoides were collected for morphological, anatomical, phytochemicals, antioxidant and essential oils investigations. A part of the plant samples was cleaned by tap water, air-dried and finely grounded for chemical analysis.

\subsubsection{Morphological and Anatomical Features}

The description of morphological and anatomical features of fresh leaves and stems of A. monosperma and L. crithmoides was undertaken according to [34,61]. The anatomical assay was performed according to [62] and modified by Peacock and Bradbury [63] as follows: the plant specimen was fixed in a solution of formalin, acetic acid and 70\% alcohol (10:5:85, $v / v / v)$. The samples were dehydrated from the fixative by immersing in tertiary butyl alcohol overnight until the dehydration process was completed. Soft paraffin was melted and poured up to two-thirds of vials for the infiltration process and then left to solidify, and returned to the vials and put in an oven $\left(60^{\circ} \mathrm{C}\right)$ until the solvent evaporated. Then soft paraffin wax, moved to hard melted paraffin wax, then placed in the oven $\left(60-62{ }^{\circ} \mathrm{C}\right)$ for two days. Plant samples were put inside the wax, and a refrigerator was used to achieve complete solidification. The block was then fixed in the microtome which was adjusted to a desired thickness (10-15 $\mu \mathrm{m}$ thick). The staining process was carried out by removing paraffin wax from the obtained sections by using xylene ( $20 \mathrm{~min}$.), followed by a mixture of absolute ethanol and xylene (1:1) for $10 \mathrm{~min}$. The dehydration of the sections was done by transmission through a sequence of 95,70 and $50 \%$ ethanol, respectively. The prepared sections were inundated for one min. in stain (fast green), rinsed with water and 
transmitted to another stain (safranin for $30 \mathrm{~min}$.). The prepared slides were water-washed and dehydrated using ethanol then sections were cleared in three alterations of xylene and placed in Canada balsam. To remove air bubbles, the slides were put in an oven for a week at $30^{\circ} \mathrm{C}$. Finally, the perfect cross-sections were chosen and examined by an automatic light microscope. Sections were photographed at $40 \times, 100 \times$, and $400 \times$ magnification.

\subsubsection{Phytochemicals Analysis}

Total phenols content was measured by the Folin-Ciocalteu (FC) colorimetric method [64]. In concise, a $5 \mathrm{ml} \mathrm{FC} \mathrm{reagent} \mathrm{(10 \% )} \mathrm{and} 4 \mathrm{ml}$ of sodium carbonate were added to one $\mathrm{ml}$ of ethanolic plant extract. The absorbance was estimated at $765 \mathrm{~nm}$. The concentration of the phenolics was estimated from the calibration curve as gallic acid equivalents (GAE)/100 g dry wt. Flavonoids content was estimated by the aluminum chloride colorimetric method [64]. Flavonoids were expressed as g catechin (CE)/100 g dry wt. Tannins amount was estimated using the vanillin hydrochloride assay [64]. The standard curve of tannins was set by 0-100 $\mu \mathrm{g}$ of tannic acid (TA). Alkaloids were measured after adding concentrated ammonium hydroxide to the extract until complete precipitation [65].

\subsubsection{Antioxidant Activity by Free Radical Scavenging Method}

The antioxidant activity of stems and leaves of $A$. monosperma. and L. crithmoides was assessed by the scavenging activity of DPPH. The half inhibitory concentration (IC50) of each extract to reduce DPPH was calculated [66].

\subsubsection{Essential Oil Analysis}

The gas chromatography-mass spectrometry (GC-MS) analysis of the essential oil from the aerial parts of both species was carried out using an instrument with the following specifications: a TRACE GC Ultra Gas Chromatographs (THERMO Scientific Corp., Waltham, USA), coupled with a THERMO mass spectrometer detector (ISQ Single Quadrupole Mass Spectrometer). The GC-MS system was equipped with a TG-5MS column $(30 \mathrm{~m} \times 0.25 \mathrm{~mm}$ i.d., $0.25 \mu \mathrm{m}$ film thickness). Analyses were carried out using helium as a carrier gas at a flow rate of $1.0 \mathrm{ml} / \mathrm{min}$ and a split ratio of 1:10 using the following temperature program: $60{ }^{\circ} \mathrm{C}$ for $1 \mathrm{~min}$; rising at $3.0^{\circ} \mathrm{C} / \mathrm{min}$. to $240{ }^{\circ} \mathrm{C}$ and held for $1 \mathrm{~min}$. The injector and detector were held at $240^{\circ} \mathrm{C}$. Diluted samples $(1: 10$ hexane, $\mathrm{v} / \mathrm{v})$ of $0.2 \mu \mathrm{L}$ of the mixtures were always injected. Mass spectra were obtained by electron ionization (EI) at $70 \mathrm{eV}$, using a spectral range of $\mathrm{m} / \mathrm{z} 40-450$. Most of the compounds were identified using the analytical method: mass spectra (authentic chemicals, Wiley spectral library collection and NSIT library).

\subsection{Statistical Analysis}

All data were expressed as the mean values \pm SE. The statistical significances among soil variables and phytochemical data were tested using the Kruskal-Wallis test (oneway analysis of variance (ANOVA)), followed by Dunn's method as multiple pairwise comparisons and Bonferroni's correction. All analyses were performed in the XLSTAT program (version 2016).

\section{Conclusions}

Concerning the ecological field, plant adaption behavior in response to environmental stress (salinity, drought, and low fertility) was evolved in structural and chemical features of plants. A. monosperma and L. crithmoides from the family Asteraceae showed critical morphological, anatomical, and phytochemical adaptation mechanisms in the Mediterranean coastal habitats of Egypt. As compared with L. crithmoides, the high antioxidant capacity of $A$. monosperma may be attributed to their high total phenols, flavonoids, alkaloids and tannins. Three groups of organic essential oils: monoterpenes, sesquiterpenes and hydrocarbons were identified in both species. Local adaptation could be assumed as a guideline or indicator for species' survival strategy, and this provides critical insights into 
the reintroduction or recovery conservation planning of the extremely small populations under the harsh conditions.

Supplementary Materials: The following are available online at https:/ / www.mdpi.com/2223-774 7/10/3/481/s1, Figure S1: Chromatogram and structures of the main components of the essential oils of A. monosperma, Figure S2: Chromatogram and structures of the main components of the essential oils of L. crithmoides.

Author Contributions: Conceptualization, G.A.E.-S.; methodology, G.A.E.-S. and M.A.; software G.A.E.-S.; formal analysis, G.A.E.-S. and M.A.; data curation, G.A.E.-S. and M.A.; writing-original draft preparation, G.A.E.-S.; writing—review and editing, M.A.D., E.M.E. and M.A. All authors have read and agreed to the published version of the manuscript.

Funding: The authors extend their appreciation to the Scientific Research Deanship at King Khalid University and the Ministry of Education in Saudi Arabia for funding this research work through the project number IFP-KKU-2020/3.

Conflicts of Interest: The authors declare no conflict of interest.

\section{References}

1. Zahran, M.A.; Willis, A.J. The Vegetation of Egypt, 2nd ed.; Springer: Amsterdam, The Netherlands, 2009.

2. Carboni, M.; Santoro, R.; Acosta, A.T.R. Dealing with Scarce Data to Understand How Environmental Gradients and Propagule Pressure Shape Fine-Scale Alien Distribution Patterns on Coastal Dunes. J. Veg. Sci. 2011, 22, 751-765. [CrossRef]

3. Ciccarelli, D. Mediterranean Coastal Sand Dune Vegetation: Influence of Natural and Anthropogenic Factors. Environ. Manag. 2014, 54, 194-204. [CrossRef] [PubMed]

4. Abdelaal, M.; Fois, M.; Fenu, G. The Influence of Natural and Anthropogenic Factors on the Floristic Features of the Northern Coast Nile Delta in Egypt. Plant Biosyst. 2018, 152, 407-415. [CrossRef]

5. Abdelaal, M.; Ahmed, D.; Fois, M.; Fenu, G.; Bacchetta, G. Floristic Patterns and Ecological Drivers of Sand Dune Ecosystem along the Mediterranean Coast of Egypt. Arid Land Res. Manag. 2019, 33, 388-411. [CrossRef]

6. Ciccarelli, D. Mediterranean Coastal Dune Vegetation: Are Disturbance and Stress the Key Selective Forces That Drive the Psammophilous Succession? Estuar. Coast. Shelf Sci. 2015, 165, 247-253. [CrossRef]

7. Bar Kutiel, P.; Katz, O.; Ziso-Cohen, V.; Divinsky, I.; Katra, I. Water Availability in Sand Dunes and Its Implications for the Distribution of Artemisia monosperma. Catena 2016, 137, 144-151. [CrossRef]

8. Ungar, I.A. Are Biotic Factors Significant in Influencing the Distribution of Halophytes in Saline Habitats? Bot. Rev. 1998, 64, 176-199. [CrossRef]

9. Perrone, R.; Salmeri, C.; Brullo, S.; Colombo, P.; De Castro, O. What Do Leaf Anatomy and Micro-Morphology Tell Us about the Psammophilous Pancratium maritimum L. (Amaryllidaceae) in Response to Sand Dune Conditions? Flora Morphol. Distrib. Funct. Ecol. Plants 2015, 213, 20-31. [CrossRef]

10. Al-Taisan, W.A. The Relation between Phenotypic Plasticity of Senecio glaucus L. and Some Soil Factors. Aust. J. Basic Appl. Sci. 2010, 4, 1369-1375.

11. Ashraf, M.; Harris, P.J.C. Photosynthesis under Stressful Environments: An Overview. Photosynthetica 2013, 51, 163-190. [CrossRef]

12. Kuster, V.C.; da Silva, L.C.; Meira, R.M.S.A.; Azevedo, A.A. Structural Adaptation and Anatomical Convergence in Stems and Roots of Five Plant Species from a "Restinga" Sand Coastal Plain. Flora Morphol. Distrib. Funct. Ecol. Plants 2018, 243, 77-87. [CrossRef]

13. Soliman, S.; Mohammad, M.G.; El-Keblawy, A.A.; Omar, H.; Abouleish, M.; Madkour, M.; Elnaggar, A.; Hosni, R.M. Mechanical and Phytochemical Protection Mechanisms of Calligonum comosum in Arid Deserts. PLoS ONE 2018, 13, e0192576. [CrossRef]

14. Edreva, A.M.; Velikova, V.B.; Tsonev, T.D. Phenylamides in Plants. Russ. J. Plant Physiol. 2007, 54, 287-301. [CrossRef]

15. Bora, K.S.; Sharma, A. The Genus Artemisia: A Comprehensive Review. Pharm. Biol. 2011, 49, 101-109. [CrossRef]

16. Abad, M.J.; Bedoya, L.M.; Apaza, L.; Bermejo, P. The Artemisia L. Genus: A Review of Bioactive Essential Oils. Molecules 2012, 17, 2542-2566. [CrossRef]

17. Hijazi, A.M.; Salhab, A.S. Effects of Artemisia monosperma Ethanolic Leaves Extract on Implantation, Mid-Term Abortion and Parturition of Pregnant Rats. J. Ethnopharmacol. 2010, 128, 446-451. [CrossRef]

18. Abu-Niaaj, L.; Abu-Zarga, M.; Abdalla, S. Isolation and Inhibitory Effects of Eupatilin, a Flavone Isolated from Artemisia monosperma Del., on Rat Isolated Smooth Muscle. Pharm. Biol. 1996, 34, 134-140. [CrossRef]

19. Al-Soqeer, A. Antioxidant Activity and Biological Evaluation of Hot-Water Extract of Artemisia monosperma and Capparis spinosa Against Lead Contamination. Res. J. Bot. 2011, 6, 11-20. [CrossRef]

20. Stavri, M.; Ford, C.H.J.; Bucar, F.; Streit, B.; Hall, M.L.; Williamson, R.T.; Mathew, K.T.; Gibbons, S. Bioactive Constituents of Artemisia monosperma. Phytochemistry 2005, 66, 233-239. [CrossRef] [PubMed]

21. Stavri, M.; Mathew, K.T.; Gibson, T.; Williamson, R.T.; Gibbons, S. New Constituents of Artemisia monosperma. J. Nat. Prod. 2004, 67, 892-894. [CrossRef] 
22. Hifnawy, M.S.; Abdel Wahab, S.M.; El-Hawary, S.S.; Karawya, M.S. Study of Essential Oil of Artemisia monosperma and Its Larvicidal Effect. Pharm. Biol. 1990, 28, 247-251. [CrossRef]

23. Zurayk, R.A.; Baalbaki, R. Inula crithmoides: A Candidate Plant for Saline Agriculture. Arid Soil Res. Rehabil. 1996, 10, 213-223. [CrossRef]

24. Andreani, S.; De Cian, M.C.; Paolini, J.; Desjobert, J.M.; Costa, J.; Muselli, A. Chemical Variability and Antioxidant Activity of Limbarda crithmoides L. Essential Oil from Corsica. Chem. Biodivers. 2013, 10, 2061-2077. [CrossRef] [PubMed]

25. Adorisio, S.; Giamperi, L.; Ada Bucchini, A.E.; Delfino, D.V.; Marcotullio, M.C. Bioassay-Guided Isolation of Antiproliferative Compounds from Limbarda crithmoides (L.) Dumort. Molecules 2020, 25, 1893. [CrossRef] [PubMed]

26. Bucchini, A.; Giamperi, L.; Ricci, D. Total Polyphenol Content, in Vitro Antifungal and Antioxidant Activities of Callus Cultures from Inula crithmoides. Nat. Prod. Commun. 2013, 8, 1587-1590. [CrossRef]

27. Jallali, I.; Waffo Téguo, P.; Smaoui, A.; Mérillon, J.M.; Abdelly, C.; Ksouri, R. Bio-Guided Fractionation and Characterization of Powerful Antioxidant Compounds from the Halophyte Inula crithmoïdes. Arab. J. Chem. 2020, 13, 2680-2688. [CrossRef]

28. Tardío, J.; Pardo-De-Santayana, M.; Morales, R. Ethnobotanical Review of Wild Edible Plants in Spain. Bot. J. Linn. Soc. 2006, 152, 27-71. [CrossRef]

29. Munns, R.; Tester, M. Mechanisms of Salinity Tolerance. Annu. Rev. Plant Biol. 2008, 59, 651-681. [CrossRef]

30. Deinlein, U.; Stephan, A.B.; Horie, T.; Luo, W.; Xu, G.; Schroeder, J.I. Plant Salt-Tolerance Mechanisms. Trends Plant Sci. 2014, 19, 371-379. [CrossRef]

31. Sardans, J.; Peñuelas, J. Plant-Soil Interactions in Mediterranean Forest and Shrublands: Impacts of Climatic Change. Plant Soil 2013, 365. [CrossRef]

32. Lamalakshmi, D.; Kumar, S.; Basanta Singh, T.; Sharma, S.K.; Beemrote, A.; Devi, C.P.; Chongtham, S.K.; Singh, C.H.; Yumlembam, R.A.; Haribhushan, A.; et al. Adaptation Strategies and Defence Mechanisms of Plants during Environmental Stress. In Medicinal Plants and Environmental Challenges; Springer: Cham, Switzerland, 2017; pp. 359-413. [CrossRef]

33. Kozlowski, T.T. Responses of Woody Plants to Flooding and Salinity. Tree Physiol. 1997, 17, 490. [CrossRef]

34. Pandey, B.P. Plant Anatomy; S. Chand \& Company Ltd.: Ram Nagar, New Delhi, 1996.

35. Abd Elhalim, M.E.; Abo-Alatta, O.K.; Habib, S.A.; Abd Elbar, O.H. The Anatomical Features of the Desert Halophytes Zygophyllum album L.F. and Nitraria retusa (Forssk.) Asch. Ann. Agric. Sci. 2016, 61, 97-104. [CrossRef]

36. Abd Elbar, O.H. Development of the Successive Cambia in Sesuvium verrucosum Raf (Aizoaceae). Ann. Agric. Sci. 2015, 60, 203-208. [CrossRef]

37. Prado, E.; Demarco, D. Laticifers and Secretory Ducts: Similarities and Differences. In Ecosystem Services and Global Ecology; IntechOpen: London, UK, 2018; pp. 103-123. [CrossRef]

38. Wink, M. Evolution of Secondary Metabolites from an Ecological and Molecular Phylogenetic Perspective. Phytochemistry 2003, 3-19. [CrossRef]

39. Agrawal, A.A.; Konno, K. Latex: A Model for Understanding Mechanisms, Ecology, and Evolution of Plant Defense Against Herbivory. Annu. Rev. Ecol. Evol. Syst. 2009, 40, 311-331. [CrossRef]

40. Hameed, A.; Gulzar, S.; Aziz, I.; Hussain, T.; Gul, B.; Khan, M.A. Effects of Salinity and Ascorbic Acid on Growth, Water Status and Antioxidant System in a Perennial Halophyte. AoB Plants 2015, 7. [CrossRef] [PubMed]

41. Selmar, D.; Kleinwächter, M. Influencing the Product Quality by Deliberately Applying Drought Stress during the Cultivation of Medicinal Plants. Ind. Crops Prod. 2013, 42, 558-566. [CrossRef]

42. Bartwal, A.; Mall, R.; Lohani, P.; Guru, S.K.; Arora, S. Role of Secondary Metabolites and Brassinosteroids in Plant Defense Against Environmental Stresses. J. Plant Growth Regul. 2013, 32, 216-232. [CrossRef]

43. Mahdavi, A.; Moradi, P.; Mastinu, A. Variation in Terpene Profiles of Thymus vulgaris in Water Deficit Stress Response. Molecules 2020, 25, 1091. [CrossRef] [PubMed]

44. Del Rio, D.; Rodriguez-Mateos, A.; Spencer, J.P.E.; Tognolini, M.; Borges, G.; Crozier, A. Dietary (Poly) Phenolics in Human Health: Structures, Bioavailability, and Evidence of Protective Effects Against Chronic Diseases. Antiox. Redox Signal. 2013, 18, 1818-1892. [CrossRef]

45. Verma, N.; Shukla, S. Impact of Various Factors Responsible for Fluctuation in Plant Secondary Metabolites. J. Appl. Res. Med. Aromat. Plants 2015, 2, 105-113. [CrossRef]

46. Yang, L.; Wen, K.S.; Ruan, X.; Zhao, Y.X.; Wei, F.; Wang, Q. Response of Plant Secondary Metabolites to Environmental Factors. Molecules 2018, 23, 762. [CrossRef]

47. War, A.R.; Paulraj, M.G.; Ahmad, T.; Buhroo, A.A.; Hussain, B.; Ignacimuthu, S.; Sharma, H.C. Mechanisms of Plant Defense Against Insect Herbivores. Plant Signal. Behav. 2012, 7, 1306-1320. [CrossRef] [PubMed]

48. Holopainen, J.K.; Blande, J.D. Where Do Herbivore-Induced Plant Volatiles Go? Front. Plant Sci. 2013, 4, 185. [CrossRef] [PubMed]

49. Roux, D.; Alnaser, O.; Garayev, E.; Baghdikian, B.; Elias, R.; Chiffolleau, P.; Ollivier, E.; Laurent, S.; El Maataoui, M.; Sallanon, H. Ecophysiological and Phytochemical Characterization of Wild Populations of Inula montana L. (Asteraceae) in Southeastern France. Flora Morphol. Distrib. Funct. Ecol. Plants 2017, 236-237, 67-75. [CrossRef]

50. Di Ferdinando, M.; Brunetti, C.; Agati, G.; Tattini, M. Multiple Functions of Polyphenols in Plants Inhabiting Unfavorable Mediterranean Areas. Environ. Exp. Bot. 2014, 103, 107-116. [CrossRef]

51. Balogun, S.O.; Oladosu, I.A.; Liu, Z. Chemical Compositions and Antioxidant Potential of Essential Oils from Leaves and Flowers of Allophylus africanus. J. Essent. Oil-Bear. Plants 2014, 17, 769-775. [CrossRef] 
52. Ishnava, K.B.; Chauhan, J.B.; Barad, M.B. Anticariogenic and Phytochemical Evaluation of Eucalyptus globules Labill. Saudi J. Biol. Sci. 2013, 20, 69-74. [CrossRef]

53. Rodriguez-Saona, C.R.; Polashock, J.; Malo, E.A. Jasmonate-Mediated Induced Volatiles in the American Cranberry, Vaccinium macrocarpon: From Gene Expression to Organismal Interactions. Front. Plant Sci. 2013, 4. [CrossRef] [PubMed]

54. Chadwick, M.; Trewin, H.; Gawthrop, F.; Wagstaff, C. Sesquiterpenoids Lactones: Benefits to Plants and People. Int. J. Mol. Sci. 2013, 14, 12780-12805. [CrossRef] [PubMed]

55. Charles, D.J.; Simon, J.E. Comparison of Extraction Methods for the Rapid Determination of Essential Oil Content and Composition of Basil. J. Am. Soc. Hortic. Sci. 2019, 115, 458-462. [CrossRef]

56. Pichersky, E.; Noel, J.P.; Dudareva, N. Biosynthesis of Plant Volatiles: Nature's Diversity and Ingenuity. Science 2006, 311, 808-811. [CrossRef] [PubMed]

57. Dunford, N.T.; Vazquez, R.S. Effect of Water Stress on Plant Growth and Thymol and Carvacrol Concentrations in Mexican Oregano Grown under Controlled Conditions. J. Appl. Hortic. 2005, 7, 20-22. [CrossRef]

58. Ben Taarit, M.; Msaada, K.; Hosni, K.; Hammami, M.; Kchouk, M.E.; Marzouk, B. Plant Growth, Essential Oil Yield and Composition of Sage (Salvia officinalis L.) Fruits Cultivated under Salt Stress Conditions. Ind. Crops Prod. 2009, 30, 333-337. [CrossRef]

59. Rivas-Martínez, S.; Rivas-Sáenz, S.; Penas-Merino, A. Worldwide Bioclimatic Classification System. Glob. Geobot. 2011, 1, 1-638. [CrossRef]

60. Estefan, G.; Sommer, R.; Ryan, J. Methods of Soil, Plant, and Water Analysis: A Manual for the West Asia and North Africa Region, 3rd ed.; International Centre for Agricultural Research in the Dry Area: Hong Kong, China, 2013.

61. Crang, R.; Lyons-Sobaski, S.; Wise, R. Plant Anatomy: A Concept-Based Approach to the Structure of Seed Plants; Springer: Switzerland, 2018.

62. Paterson, R.A. Botanical Histochemistry; Principles and Practices; Jensen, W.A., Ed.; Freeman: San Francisco, CA, USA, 1963. [CrossRef]

63. Peacock, P.; Bradbury, S. Peacock's Elementary Micro-Technique, 4th ed.; Edward Arnold: London, UK, 1973.

64. Sadasivam, S.; Manickam, A. Biochemical Methods for Agricultural Science; Wiley Eastern Limited: New Delhi, India, 1992.

65. Harborne, J.B. Phytochemical Methods: A Guide to Modern Techniques of Plant Analysis, 2nd ed.; Chapman and Hall: New York, NY, USA, 1984

66. Kitts, D.D.; Wijewickreme, A.N.; Hu, C. Antioxidant Properties of a North American Ginseng Extract. Mol. Cell. Biochem. 2000, 203. [CrossRef] 